\title{
Carcass characteristics and meat quality of Holstein-Friesian $x$ Hereford cattle of different sex categories and slaughter ages
}

\author{
Paulina Pogorzelska-Przybyłek ${ }^{1}$, Zenon Nogalski ${ }^{1}$, Monika Sobczuk-Szul ${ }^{1}$, Cezary Purwin $^{2}$, and \\ Dorota Kubiak $^{3}$ \\ ${ }^{1}$ Department of Cattle Breeding and Milk Evaluation, University of Warmia and Mazury in Olsztyn, \\ Oczapowskiego 5/137, 10-958 Olsztyn-Kortowo, Poland \\ ${ }^{2}$ Department of Animal Nutrition and Feed Science, Faculty of Animal Bioengineering, University of Warmia \\ and Mazury in Olsztyn, ul. Oczapowskiego 5/248, 10-719 Olsztyn, Poland \\ ${ }^{3}$ Department of Commodity Science and Animal Raw Material Processing, University of Warmia and Mazury \\ in Olsztyn, Oczapowskiego 5/162, 10-958 Olsztyn-Kortowo, Poland
}

Correspondence: Paulina Pogorzelska-Przybyłek (paulina.pogorzelska@uwm.edu.pl)

Received: 15 November 2017 - Revised: 25 April 2018 - Accepted: 25 May 2018 - Published: 28 June 2018

\begin{abstract}
When dairy cattle production predominates, the quantity and quality of beef can be increased through commercial crossing of beef bulls with dairy cows and creating herds for the purpose of beef production. This experiment was conducted to compare carcass traits in young bulls and steers, produced by crossing HolsteinFriesian (HF) cows with Hereford (HH) bulls and slaughtered at 15 and 18 months of age. One half of 32 young bulls were castrated at 2 or 3 weeks of age. Starting at 7 months of age, they received grass silage supplemented with concentrates. At the end of the fattening period, the animals were slaughtered, carcass quality and the quality of meat from m. longissimus thoracis were evaluated. It was found that unlike steers, bulls can be slaughtered at a later age because their carcass traits improved over time and carcass fat content increased only insignificantly. Meat from steers had higher intramuscular fat content (1.20 and $2.35 \%$ in bulls and steers slaughtered at 15 months of age, respectively; 1.89 and $3.79 \%$ in bulls and steers slaughtered at 18 months of age, respectively), it was tenderer and juicier than meat from bulls, and its sensory quality improved with age. The intramuscular fat (IMF) of steers was characterized by a more desirable $n-6 / n-3$ polyunsaturated fatty acid (PUFA) ratio, whereas the IMF of bulls had higher concentrations of conjugated linoleic acid and n-3 PUFAs. Beef from steers is a good choice for consumers who appreciate high-quality meat. The results of this study may encourage producers to raise steers for beef.
\end{abstract}

\section{Introduction}

Beef intended for human consumption is provided by beef cattle which account for less than $1 \%$ of the total Polish cattle population. Therefore, beef production in Poland is based on dairy cattle herds. However, the carcasses and meat of dairy cattle are characterized by lower quality compared with purebred and crossbred beef cattle (Litwińczuk et al., 2012; Nogalski et al., 2013b). In order to improve the quality of beef, selected dairy heifers and cows are inseminated with the semen of beef bulls. Research results show that com- mercial crossing not only contributes to higher growth rates and better feed conversion ratios in the offspring, but it also improves carcass conformation and meat quality (Nogalski and Kijak, 2001; Christensen et al., 2011). However, fattening performance is also determined by the choice of beef cattle breeds for crossing and the intensity and duration of fattening (Nogalski et al., 2014a). A previous study, which investigated bulls and steers produced by crossing HolsteinFriesian cows with late-maturing Charolais bulls, revealed that both bulls and steers should be slaughtered at a later age (18 months) rather than at an earlier age (15 months) 
(Nogalski et al., 2018). Semi-intensive fattening of Polish Holstein Friesian $\times$ Limousin bulls to a slaughter weight of $600 \mathrm{~kg}$ is recommended due to an increase in carcass value. Steers should be fattened to a slaughter weight of $500-550 \mathrm{~kg}$ to prevent excessive fat deposition (Nogalski et al., 2014a). Beef from steers currently has a high market share across the world (Reddy et al., 2015). In some European countries, young cattle raised for beef include bulls, heifers and, less frequently, steers (Integrated Agricultural Market Information System, 2017). In countries that are leaders in beef production, meat from steers remains in high demand because it responds to changing consumer preferences. Meat from steers has higher intramuscular fat (IMF) content (Prado et al., 2015), which contributes to its flavor, tenderness and a lighter color (Moletta et al., 2014). In comparison with bulls, steers are more docile and easier to handle because castration lowers blood testosterone levels (Nogalski, 2015). Thus, they can be grazed together with other animals. Due to the low profitability of beef cattle production, the animals are fed mostly cheap farm-made feeds in a semi-intensive system. The advantage of steers is that they do not require very high energy concentrations in the ration and are less sensitive to changes in dietary protein levels than bulls (Sharman et al., 2013). Steer beef production could gain more popularity if research findings were updated regularly and if models of beef production from steers were developed. It could offer a viable alternative to local farmers who resign from milk production due to the end of EU milk quotas. In view of the above, the aim of this study was to compare carcass traits and meat quality in bulls and steers produced by crossing Holstein-Friesian (HF) cows with bulls of the early maturing Hereford $(\mathrm{HH})$ breed, slaughtered at different ages.

\section{Materials and methods}

\subsection{Animals}

The study was conducted in 2013-2014 upon the approval of the Local Ethics Committee for Animal Experimentation (decision no. 121/2010).

The experimental materials comprised crossbred $(\mathrm{HF} \times \mathrm{HH})$ beef bulls (16 animals) and steers (16 animals), produced by crossing HF heifers and cows with $\mathrm{HH}$ bulls. Calves of known origin purchased at 2 or 3 weeks of age were placed in a rearing facility at the Agricultural Experiment Station in Bałcyny. The calves were kept in group pens (16 animals per pen) on deep litter. One half of the calves (one pen) were castrated at purchase. Bloodless castration was carried out using a rubber elastrator. The calves remained under veterinary care.

At 6 months of age, bulls and steers were placed in a fattening facility, in four pens with eight animals per pen, depending on gender and slaughter age (bulls - 15 months; bulls -18 months; steers -15 months; steers -18 months). Their average daily gain was assumed to be $1000 \mathrm{~g}( \pm 50 \mathrm{~g})$.
The average nutritional value of diets per kilogram DM (dry matter) was 1.05 UFV (feed unit for meat production) and $166 \mathrm{~g}$ total protein. The animals received concentrate I to body weight of $300 \mathrm{~kg}$, followed by concentrate II ( $>300 \mathrm{~kg}$ body weight) (Table 1 ).

The animals were fed a total mixed ration (TMR) ad libitum. TMR was composed of grass silage and concentrate (triticale, rapeseed meal, premix). The proportions of silage and concentrate in the ration were calculated based on energy density (ED) values, as recommended in the INRA feeding system for growing and fattening beef cattle (National Research Institute of Animal Production - INRA, 2009). The diets were formulated based on the amounts of protein digested in the small intestine, PDIN (protein digested in the small intestine depending on rumen-degraded protein) and PDIE (protein digested in the small intestine depending on rumen-fermented organic matter) (National Research Institute of Animal Production - INRA, 2009). The proportions were adjusted at 4-week intervals based on an updated analysis of silage.

Bulls and steers were fattened until 15 and 18 months of age. Due to a small difference in slaughter age, the animals were slaughtered in three batches. At the end of the fattening period, they were transported over a distance of $90 \mathrm{~km}$ to the abattoir (bulls and steers were separated) where they were kept in lairage for $15-20 \mathrm{~h}$ prior to slaughter, in individual boxes with free access to water. The animals were weighed and slaughtered in accordance with industrial standards. They were stunned and bled, and the carcasses were dressed and split into two sides that were chilled for $96 \mathrm{~h}$ at $4{ }^{\circ} \mathrm{C}$. Electrical stimulation was not applied to the carcasses. Halfcarcasses were weighed using an in-line automatic scale, within an accuracy of $0.5 \mathrm{~kg}$, and carcass conformation and fat cover were evaluated in accordance with the EUROP system. The surface area of $\mathrm{m}$. longissimus thoracis (LT) was outlined on wax paper, between the 10th and 11th thoracic vertebrae, and was measured with a planimeter. The carcass dressing percentage (percentage ratio of carcass weight to live body weight at slaughter) was calculated. Ninety-six hours post mortem, three-rib (10th-12th rib) sections were sampled from right half-carcasses (two cuts through a halfcarcass, perpendicular to the spine, between the 9th and 10th, and the 12th and 13th thoracic vertebrae). Half-carcasses were divided into primal cuts in accordance with the Polish Standard of 2004 (PN-88/A-82003/Ap1:2004, 2004). The five most valuable cuts, i.e. the shoulder, fore ribs, best ribs, loin and round, were weighed and their percentage share in the right half-carcass was estimated. Three-rib cuts were dissected, and the percentage content of soft tissues (lean meat, fat, tendons) and bones was determined. During carcass dressing, LT samples were collected from the loin at the level of the 11th-13th thoracic vertebrae, to evaluate beef quality. Meat samples weighing approximately $300 \mathrm{~g}$ were packaged in PA/PE (polyamide/polyethylene) vacuum bags at an ambient temperature of around $4{ }^{\circ} \mathrm{C}$, under standard 
Table 1. Chemical composition and nutritional value of experimental diets (mean $\pm S D$ ).

\begin{tabular}{lrrrrr}
\hline Specification & Silage $^{\mathrm{g}}$ & Triticale & Rapeseed meal & Concentrate I & Concentrate II \\
\hline$N$ & 9 & 5 & 5 & 7 & 7 \\
Dry matter (\%) & $39.7 \pm 10.93$ & $88.1 \pm 0.22$ & $88.7 \pm 0.21$ & $88.4 \pm 0.71$ & $88.5 \pm 0.82$ \\
On dry matter basis (\%) & & & & & \\
Organic matter & $92.0 \pm 3.06$ & $98.1 \pm 0.25$ & $92.7 \pm 0.27$ & $93.2 \pm 1.31$ & $92.5 \pm 1.83$ \\
Crude protein & $14.1 \pm 1.14$ & $13.3 \pm 0.70$ & $38.8 \pm 0.85$ & $18.9 \pm 1.51$ & $16.3 \pm 0.71$ \\
NDF $^{\mathrm{a}}$ & $56.9 \pm 5.23$ & $19.3 \pm 0.10$ & $31.0 \pm 0.11$ & $20.2 \pm 1.12$ & $18.4 \pm 0.79$ \\
$\mathrm{ADF}^{\mathrm{b}}$ & $38.7 \pm 5.92$ & $4.4 \pm 0.02$ & $22.8 \pm 0.12$ & $7.2 \pm 0.58$ & $3.1 \pm 0.82$ \\
DOMD $^{\mathrm{C}}$ & $7.4 \pm 5.59$ & $93.2 \pm 2.65$ & $84.8 \pm 0.41$ & - & - \\
PDV $^{\mathrm{d}}$ & $0.1 \pm 0.03$ & $0.1 \pm 0.00$ & $0.1 \pm 0.00$ & $0.1 \pm 0.00$ & $0.1 \pm 0.00$ \\
PDIE $^{\mathrm{f}}$ & $8.2 \pm 6.64$ & $8.9 \pm 0.03$ & $25.9 \pm 0.09$ & $12.2 \pm 0.24$ & $11.2 \pm 0.52$ \\
\hline
\end{tabular}

a Neutral detergent fiber.

b Acid detergent fiber.

c Organic matter digestibility.

$\mathrm{d}$ Meat production units.

e Protein digested in the small intestine depending on rumen-degraded protein.

${ }^{\mathrm{f}}$ Protein digested in the small intestine depending on rumen-fermented organic matter.

$\mathrm{g}$ Fermentation characteristics of silage: $\mathrm{pH}-4.8 \pm 0.3$; lactic acid $-54 \pm 20.4$; volatile fatty acids $-27 \pm 5.3$; water-soluble carbohydrates -

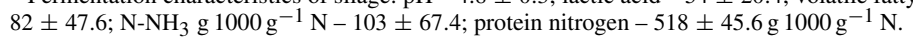

industrial conditions. The samples were transported in an isothermal container to the research laboratory of the Department of Commodity Science and Processing of Animal Raw Materials at the University of Warmia and Mazury in Olsztyn, where they were analyzed to determine the proximate chemical composition, physicochemical properties and sensory attributes of beef. LT samples were subjected to quantitative and qualitative analyses.

\subsection{Fat extraction and fatty acid profile}

The fatty acid (FA) profile of IMF extracted from LT samples was determined in the research laboratory of the Department of Cattle Breeding and Milk Quality Evaluation at the University of Warmia and Mazury in Olsztyn. Intramuscular fat (IMF) was extracted from ground meat samples in the Büchi B-811 extraction system, according to the Soxhlet method, with hexane as the solvent. Fatty acid methyl esters were obtained by dissolving the extracted fat in a methanol-chloroform- $\mathrm{H}_{2} \mathrm{SO}_{4}$ mixture, followed by methylation according to the modified Peisker method (Żegarska et al., 1991). The percentage share of 33 FAs was determined by gas chromatography, using the Varian CP 3800 system with a split-splitless injector and a flame-ionization detector (FID). Samples $(1 \mu \mathrm{L})$ of fatty acid methyl esters were placed on a CP-Sil 88 capillary column (length: $100 \mathrm{~m}$; inner diameter: $0.25 \mathrm{~mm}$ ). Data were processed using the GALAXIE Chromatography Data System. Fatty acids were identified by comparing their retention times with those of commercially available reference standards purchased from Supelco, Inc. Analyses of samples and reference standards were performed under identical conditions: carrier gas - helium; injector temperature $-260^{\circ} \mathrm{C}$; detector temperature $-260^{\circ} \mathrm{C}$; and initial oven temperature $-110^{\circ} \mathrm{C}$; raised to $249^{\circ} \mathrm{C}$. Fatty acids were divided into the following types: saturated fatty acids (SFAs), unsaturated fatty acids (UFAs), monounsaturated fatty acids (MUFAs) and polyunsaturated fatty acids (PUFAs). The following ratios were calculated: PUFA / SFA, MUFA / SFA and n-6 / n-3 PUFA.

\subsection{Chemical composition, physical properties and sensory attributes of $\mathrm{m}$. longissimus thoracis}

Meat color was determined based on the values of CIE LAB coordinates, $L^{*}$ (lightness), $a^{*}$ (redness) and $b^{*}$ (yellowness). Color space parameters $L^{*}, a^{*}$ and $b^{*}$ were measured three times by the reflectance method, using a HunterLab MiniScan XE Plus spectrocolorimeter, at different points over the muscle cross section area. After color measurements, each sample was divided into two portions: the first portion was used to determine the proximate chemical composition (\%) and physicochemical properties of meat, and the other portion was used to evaluate the sensory properties of meat.

The analysis of the proximate chemical composition of meat included the determination of dry matter, total protein, fat and minerals in ash form, according to the procedure proposed by Wajda et al. (2014). The following physicochemical properties of meat were determined: ultimate $\mathrm{pH}-$ with the use of a combination double pore electrode (Hamilton) and a $\mathrm{pH} 340 \mathrm{i} \mathrm{pH}$ meter equipped with a TFK 150/E temperature sensor (WTW); water-holding capacity - based on cooking loss (meat samples were weighed to determine their initial weight, they were packaged in plastic bags and placed in a water bath at a temperature of $80^{\circ} \mathrm{C}$ for $1 \mathrm{~h}$; then the samples were cooled for 30 min under running wa- 
Table 2. Slaughter value of bulls and steers.

\begin{tabular}{|c|c|c|c|c|c|c|c|c|}
\hline \multirow{2}{*}{$\begin{array}{l}\text { Sex category } \\
\text { Age at slaughter (months) }\end{array}$} & \multicolumn{2}{|c|}{ Bulls } & \multicolumn{2}{|c|}{ Steers } & \multirow[t]{2}{*}{ SEM } & \multicolumn{3}{|c|}{$P$ value } \\
\hline & 15 & 18 & 15 & 18 & & $C$ & $A$ & $C \times A$ \\
\hline Body & 82.5 & 586.4 & 459.5 & 564.0 & 12.664 & 0.204 & 0.000 & 0.986 \\
\hline Dressing percenta & 57.04 & 59.01 & 56.45 & 56.18 & 0.319 & 0.003 & 0.117 & 0.041 \\
\hline Conformation score $^{\mathrm{a}}$ (pts) & 7.5 & 7.6 & 6.1 & 7.9 & 0.238 & 0.203 & 0.038 & 0.070 \\
\hline Fatness score ${ }^{\mathrm{b}}(\mathrm{pts})$ & 4.3 & 5.1 & 6.4 & 8.6 & 0.415 & 0.000 & 0.017 & 0.271 \\
\hline Five most valuable $\mathrm{p}$ & 4.56 & 109.56 & 79.96 & 94.75 & 2.482 & 0.003 & 0.000 & 0.098 \\
\hline Five most valuable primal cuts $(\%)$ & 62.60 & 62.81 & 62.14 & 61.71 & 0.263 & 0.151 & 0.834 & 0.549 \\
\hline M. longissimus thoracis area $\left(\mathrm{cm}^{2}\right)$ & 89.00 & 94.88 & 80.25 & 94.25 & 2.204 & 0.260 & 0.021 & 0.327 \\
\hline
\end{tabular}

${ }^{a}$ EUROP conformation: 1 to 15 , with 1 being very lean and 15 being outstandingly muscled.

b EUROP degree of fat cover: 1 to 15 , with 1 being very lean and 15 being very fat.

The five most valuable primal cuts included the shoulder, fore ribs, best ribs, loin and round; $C$, significant effect of sex category (bulls - steers);

$A$, significant effect of age at slaughter (15-18 months); $C \times A$, significant effect of interaction.

The $P$ value in bold is significant.

ter, dried and weighed again to determine their weight after cooking; cooking loss was calculated as the difference between sample weights before and after heat treatment) and natural drip loss (approx. $20 \mathrm{~g}$ meat samples were packaged in polyethylene string bags and placed in an incubator at a temperature of $4 \pm 1{ }^{\circ} \mathrm{C}$; after $24 \mathrm{~h}$, the samples were dried and weighed again within an accuracy of $0.001 \mathrm{~g}$; natural drip loss was calculated as the difference between sample weights before and after cold storage); shear force - after thermal processing, with the use of a Warner-Bratzler head $(500 \mathrm{~N}$, speed $100 \mathrm{~mm} \mathrm{~min}^{-1}$ ) attached to an INSTRON 5542 universal testing machine.

The sensory attributes of meat were evaluated during three sessions because the animals were slaughtered in three batches. Meat samples ( $200 \mathrm{~g})$ were cut out across the muscle fibers and were cooked in a $0.6 \% \mathrm{NaCl}$ solution (meat to solution weight ratio of $1: 2$ ) at a temperature of $96^{\circ} \mathrm{C}$ $\left( \pm 2{ }^{\circ} \mathrm{C}\right)$. Pasteurization was carried out until the temperature inside the sample reached $75^{\circ} \mathrm{C}$ (Baryłko-Pikielna et al., 1964). The sensory attributes of coded meat samples (aroma, taste, juiciness and tenderness) were evaluated on a five-point scale (where 1 and 5 denoted the minimum and maximum score, respectively) by five trained panelists, selected based on their flavor sensitivity, according to Polish standards (PN-ISO 4121:1998, 1998). The samples were presented to the panelists at room temperature (approx. $20^{\circ} \mathrm{C}$ ), in fluorescent light. The panelists assessed 10 to 11 meat samples during each session; each panelist received coded samples in the same order, and each sample was tested by all panelists.

\subsection{Statistical analysis}

The results were analyzed statistically using Statistica 10 software (StatSoft Inc., Tulsa, OK, USA). The effects of sex category and slaughter age on carcass traits and meat quality were determined by the least squares method, using the following formula:

$Y_{i j k}=\mu+A_{i}+B_{j}+(A B) i j+e_{i j k}$,

where $Y_{i j}$ is the value of the analyzed parameter, $\mu$ is the population mean, $A_{i}$ is the effect of sex category $(1,2), B_{j}$ is the effect of slaughter age $(1,2),(A B)_{i j}$ is the sex category $\times$ slaughter age interaction and $e_{i}$ is random error.

The data in the tables are presented as least square means (LSM) and standard errors of the mean (SEM).

\section{Results and discussion}

No significant differences in live body weight before slaughter were found between bulls and steers. As expected, this parameter was highly significantly influenced by age at slaughter (Table 2). Carcass dressing percentage was highly significantly higher in bulls. In the present study, the average carcass dressing percentage of bulls and steers slaughtered at 15 months of age was slightly lower than that of purebred HH bulls (57.1\%), reported by Sakowski et al. (2001) 15 years ago. In comparison with purebred $\mathrm{HH}$ bulls $(55.3 \%)$ slaughtered at the same age and crossbred (Charolais $\times \mathrm{HH}$ ) bulls slaughtered at 18 months of age (56.9\%) during experiments conducted 11 and 7 years ago, respectively (Miciński et al., 2005; Kamieniecki et al., 2009), the HF $\times$ HH bulls analyzed in the present study were characterized by higher values of carcass dressing percentage. This testifies to the high effectiveness of breeding programs aimed at improving performance traits in $\mathrm{HH}$ cattle and desirable changes in the national $\mathrm{HH}$ cattle population. The carcass dressing percentage of steers, determined in our study, was higher than that of crossbred $\mathrm{HF} \times$ Limousin $(\mathrm{LM})$ steers raised under identical housing and feeding conditions and slaughtered at the same ages, which reached 54.46 and $54.85 \%$ in steers slaughtered at 15 and 18 months of age, respectively (Nogalski et al., 2013a). 
Table 3. Tissue composition of three-rib sections.

\begin{tabular}{lrr|rr|r|rrr}
\hline Sex category & \multicolumn{2}{c|}{ Bulls } & \multicolumn{2}{c|}{ Steers } & SEM & \multicolumn{3}{c}{$P$ value } \\
\hline Age at slaughter (months) & 15 & 18 & 15 & 18 & & $C$ & $A$ & $C \times A$ \\
\hline Weight of the three-rib section $(\mathrm{kg})$ & 5.85 & 8.26 & 6.41 & 8.37 & 0.254 & $\mathbf{0 . 0 3 2}$ & $\mathbf{0 . 0 0 2}$ & $\mathbf{0 . 0 4 2}$ \\
\hline Composition of the three-rib section $(\%):$ & & & & & & & \\
Fat & 15.90 & 18.32 & 26.26 & 35.44 & 1.542 & $\mathbf{0 . 0 0 0}$ & $\mathbf{0 . 0 0 1}$ & $\mathbf{0 . 0 3 0}$ \\
Muscles & 55.27 & 56.11 & 49.33 & 44.84 & 0.981 & $\mathbf{0 . 0 0 0}$ & 0.210 & $\mathbf{0 . 0 4 5}$ \\
Bones & 23.44 & 21.46 & 19.53 & 15.20 & 0.658 & $\mathbf{0 . 0 0 0}$ & $\mathbf{0 . 0 0 1}$ & 0.368 \\
Tendons & 5.39 & 4.88 & 4.88 & 3.28 & 0.378 & 0.930 & $\mathbf{0 . 0 0 3}$ & 0.052 \\
\hline
\end{tabular}

$C$, significant effect of sex category (bulls-steers); $A$, significant effect of age at slaughter (15-18 months); $C \times A$, significant effect of interaction.

The $P$ value in bold is significant

In bulls, the fatness score ranged from 4.3 to 5.1 points, which corresponded to fat cover class 3 (2- to 2$)$ in the EUROP classification system, and it was lower than the fat score of steers slaughtered at the same age (classes $2+$ to $3+)$. The fat content of the three-rib section was 26.26 and $35.44 \%$ in steers slaughtered at 15 and 18 months of age, respectively (Table 3). The animals slaughtered at 18 months of age had better-conformed carcasses than those slaughtered at 15 months of age $(P<0.05)$. Apart from dressing percentage, carcass quality should also be evaluated based on the weight and percentage share of the most valuable cuts (shoulder, fore ribs, best ribs, loin and round). Carcass dressing percentage is related to body weight (Macedo et al., 2008), which is affected by the contents of the gastrointestinal tract, breed and age of animals (Missio et al., 2009). The weight of five most valuable cuts was affected by both age at slaughter and sex category. The values of this parameter were higher in bulls than in steers and in older animals than in younger individuals. It should be noted that the weight of the five most valuable cuts increased in bulls by $25 \mathrm{~kg}$ over 3 months, whereas the percentage content of those cuts in the half-carcass remained unchanged. This indicates that bulls should be fattened for a longer period of time. Such a trend was also observed in steers, but it was less pronounced, which could result from the increasing fat content of their carcasses. The cross section of LT increased significantly with age $(P<0.05)$. No difference in the values of this parameter was noted between bulls and steers slaughtered at 18 months of age.

Beef carcass quality is also affected by tissue composition (Table 3). Carcasses with the highest lean content, lowest bone content and optimal fat content, which is associated with higher sensory scores, are considered most desirable (Nogalski et al., 2013a). Highly significant differences in the percentage of fat in the three-rib section between bulls and steers correspond to the results of carcass classification based on the EUROP scale. In comparison with bull carcasses, steer carcasses had higher fat content and lower muscle content. Similar relationships were observed in a previous study of crossbred bulls and steers, the offspring of HF cows and bulls of the late-maturing Charolais breed (Nogalski et al., 2018). In the current experiment, age at slaughter influenced the percentage of tendons in the three-rib section, which was higher in animals slaughtered at an earlier age. The decrease in the percentage of bones in the three-rib section of older animals resulted from age-related fat deposition in the carcass. Age at slaughter had no significant effect on the percentage of muscles in the three-rib section.

Previous research supports the argument that grass-fed beef (on a $\mathrm{g} / \mathrm{g}$ fat basis) has a more desirable SFA lipid profile than grain-fed beef, including a higher concentration of the cholesterol neutral SFA C18:0 and lower concentrations of cholesterol elevating SFAs C14:0 and C16:0 (Leheska et al., 2008; Alfaia et al., 2009). Grass-finished beef is also higher in total conjugated linoleic acid (CLA; C18:2) isomers, TVA (trans-vaccenic acid) (C18:1 t11) and n-3 PUFAs on a $\mathrm{g} / \mathrm{g}$ fat basis. Grain-fed beef consumers may achieve similar intakes of both n-3 PUFAs and CLA through the consumption of higher fat portions with higher overall palatability scores (Daley et al., 2010). In a study by WielgoszGroth et al. (2016), fat from steers had significantly lower SFA content $(51.28 \%)$ and higher UFA content $(53.50 \%)$ than fat from bulls. In the present experiment, the concentrations of SFAs and UFAs did not differ significantly between sex categories or age groups (Table 4).

Differences were noted with regard to MUFA levels which were higher in fat from steers than in fat from bulls, due to highly significantly higher PUFA concentrations in bulls. Such a relationship was also reported by Nogalski et al. (2014b), who analyzed the FA profile in crossbred $\mathrm{HF} \times \mathrm{LM}$ bulls and steers slaughtered at different weights $(450,500,550$ and $600 \mathrm{~kg})$. An age-related decrease was noted in the PUFA content of IMF in LT. The decrease was not statistically significant, similarly to the effect exerted by age at slaughter on the percentages and ratios of 15 FAs. The gender of animals had a significant influence on FA ratios (PUFA / SFA, MUFA / SFA, n-6 / n-3 PUFA). Based on the current nutritional recommendations of the 10 UK De- 
Table 4. Content of functional fatty acids, fatty acid groups and ratios in intramuscular fat (IMF) from m. longissimus thoracis.

\begin{tabular}{|c|c|c|c|c|c|c|c|c|}
\hline \multirow{2}{*}{$\begin{array}{l}\text { Sex category } \\
\text { Age at slaughter (months) }\end{array}$} & \multicolumn{2}{|c|}{ Bulls } & \multicolumn{2}{|c|}{ Steers } & \multirow[t]{2}{*}{ SEM } & \multicolumn{3}{|c|}{$P$ value } \\
\hline & 15 & 18 & 15 & 18 & & $C$ & $A$ & $C \times A$ \\
\hline \multicolumn{9}{|c|}{ Main groups of fatty acids ( $\%$ total fatty acids): } \\
\hline SFA & 50.78 & 49.43 & 49.78 & 49.38 & 0.454 & 0.578 & 0.355 & 0.613 \\
\hline UFA & 49.22 & 50.57 & 50.22 & 50.62 & 0.454 & 0.538 & 0.328 & 0.572 \\
\hline MUF & 41.91 & 43.53 & 45.87 & 47.21 & 0.640 & 0.002 & 0.189 & 0.900 \\
\hline $\mathrm{P}$ & 7.31 & 7.04 & 4.36 & 3.41 & 0.475 & 0.000 & 0.436 & 0.666 \\
\hline n-6 PU & 5.02 & 4.89 & 2.80 & 2.13 & 0.352 & 0.000 & 0.479 & 0.642 \\
\hline n-3 PUFA & 1.89 & 1.72 & 1.21 & 1.15 & 0.122 & 0.010 & 0.603 & 0.810 \\
\hline \multicolumn{9}{|l|}{ FA ratio } \\
\hline PUFA/SFA & 0.15 & 0.14 & 0.09 & 0.07 & 0.010 & 0.000 & 0.501 & 0.654 \\
\hline MUFA/SFA & 0.83 & 0.88 & 0.92 & 0.96 & 0.020 & 0.032 & 0.206 & 0.866 \\
\hline n-6 / n-3 PUFA & 2.76 & 2.80 & 2.44 & 1.93 & 0.108 & 0.003 & 0.209 & 0.139 \\
\hline \multicolumn{9}{|l|}{ Fatty acids in IMF $(\mathrm{g} / 100 \mathrm{~g})$ : } \\
\hline CLA & 0.27 & 0.29 & 0.21 & 0.20 & 0.013 & 0.003 & 0.882 & 0.412 \\
\hline C20:5 EPA & 0.17 & 0.14 & 0.10 & 0.06 & 0.016 & 0.017 & 0.282 & 0.869 \\
\hline C22:5 DPA & 0.37 & 0.37 & 0.3 & 0.20 & 0.029 & 0.029 & 0.376 & 0.326 \\
\hline C22:6 DHA & 0.18 & 0.04 & 0.08 & 0.08 & 0.041 & 0.718 & 0.426 & 0.394 \\
\hline
\end{tabular}

MUFA, monounsaturated fatty acids; PUFA, polyunsaturated fatty acids; CLA, conjugated linoleic acid; EPA, eicosapentaenoic acid; DPA, docosapentaenoic acid; DHA, docosahexaenoic acid; $C$, significant effect of sex category (bulls-steers); $A$, significant effect of age at slaughter (15-18 months); $C \times A$, significant effect of interaction.

The $P$ value in bold is significant.

partment of Health (1994), the n-6 / n-3 PUFA ratio should not exceed 4.0. According to FAO (2008), a high n-6/n-3 PUFA ratio is associated with an increased risk of colorectal cancer, prostate cancer and breast cancer. Since a risk associated with n-6 PUFAs has not been demonstrated to date, it can be concluded that low n-3 PUFA intake is responsible for the observation. In our study, highly significant differences in the $n-6 / n-3$ PUFA ratio were found between bulls and steers. The values of the n- 6 / n-3 PUFA ratio were within the recommended limits in both sex categories, but they were more desirable in fat from steers (1.93-2.44). The IMF extracted from bulls had highly significantly higher concentrations of CLA, significantly higher concentrations of $n$ 3 PUFAs : eicosapentaenoic acid (C20:5 EPA) and dipicolinic acid (C22:5 DPA), and a more desirable PUFA / SFA ratio. The levels of biologically active fatty acids in fat from steers were low, in comparison with those reported by Realini et al. (2004) in intensively fed HH steers $(0.30,0.56$

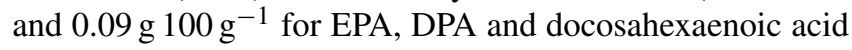
(DHA), respectively).

Proximate chemical composition is frequently subjected to laboratory analyses because it determines the nutritional value and processing suitability of meat. In comparison with meat from other animal species, beef has relatively low energy content and high biological value. The low energy value of beef results from its low IMF content, and its high nutritional value is due to its relatively high (approx. 20\%) protein content. The protein content of beef determined in our study was even higher (Table 5). Apart from nutritional value, the taste, tenderness and juiciness of beef are also affected by its chemical composition. Marbling, i.e. IMF content, has a positive influence on the sensory properties of beef such as juiciness and flavor. According to Miller et al. (2000), the fat flavor intensifies with an increase in IMF content. A year later, Miller (2001) demonstrated that the minimal level of IMF in beef for consumer acceptance and preference is approximately $3 \%$, whereas fat levels above $7.3 \%$ may have a negative effect on flavor perception and acceptability. In the present study, such a trend was observed in meat from steers. The lower fat content, noted in our study, did not significantly decrease the flavor score. The analysis of the proximate chemical composition of beef revealed a 2fold higher $(P<0.001)$ IMF content of LT in steers. Sex category also influenced cooking loss $(\%)$, which was lowest in steers slaughtered at 18 months of age. Age at slaughter had no significant effect on cooking loss. Ahnström et al. (2012) compared cooking loss between two slaughter ages (18 and 22 months) and found that the values were lower in 22-month-old samples, which could be partially explained by higher IMF content at 22 months of age.

Beef quality is considerably affected by $\mathrm{pH}$ measured $48 \mathrm{~h}$ postmortem (Filipcik et al., 2009). In the present study, the $\mathrm{pH}$ of beef confirmed its high eating quality ( $\mathrm{pH}$ of 5.4-5.8, Sakowski et al., 2001) and suitability for aging. Many compounds contributing to beef flavor are water-soluble. As $\mathrm{pH}$ increases in meat, the proteins have increased water binding properties. During cooking, fewer water-soluble proteins are lost from high $\mathrm{pH}$ meat since there is less cooking loss 
Table 5. Chemical composition, physical properties and sensory properties of $\mathrm{m}$. longissimus thoracis.

\begin{tabular}{lrr|rr|r|r|rrr}
\hline Sex category & \multicolumn{2}{c}{ Bulls } & \multicolumn{2}{c|}{ Steers } & SEM & \multicolumn{3}{c}{$P$ value } \\
\hline Age at slaughter (months) & 15 & 18 & 15 & 18 & & $C$ & $A$ & $C \times A$ \\
\hline Dry matter (\%) & 25.10 & 25.63 & 25.97 & 27.23 & 0.299 & 0.135 & 0.303 & 0.054 \\
Fat (\%) & 1.20 & 1.89 & 2.35 & 3.79 & 0.333 & $\mathbf{0 . 0 0 4}$ & 0.385 & 0.062 \\
Ash (\%) & 1.09 & 1.09 & 1.07 & 1.07 & 0.006 & 0.136 & 0.670 & 0.870 \\
Total protein (\%) & 21.88 & 22.06 & 21.99 & 21.70 & 0.100 & 0.556 & 0.282 & 0.793 \\
pH 48 & 5.57 & 5.59 & 5.53 & 5.48 & 0.025 & 0.648 & 0.494 & 0.397 \\
$L^{*}$ & 35.34 & 36.01 & 35.73 & 36.84 & 0.571 & 0.623 & 0.861 & 0.478 \\
$a^{*}$ & 17.95 & 18.24 & 18.41 & 18.87 & 0.325 & 0.443 & 0.906 & 0.590 \\
$b^{*}$ & 13.54 & 13.51 & 13.67 & 14.56 & 0.292 & 0.337 & 0.456 & 0.484 \\
Cooking loss (\%) & 34.78 & 35.17 & 34.07 & 32.13 & 0.539 & $\mathbf{0 . 0 4 4}$ & 0.269 & 0.454 \\
Natural drip loss (\%) & 2.16 & 2.55 & 1.81 & 1.75 & 0.203 & 0.184 & 0.592 & 0.702 \\
WBSF (N) & 45.54 & 48.46 & 37.76 & 37.05 & 2.829 & $\mathbf{0 . 0 4 5}$ & 0.756 & 0.749 \\
Aroma & 4.6 & 4.2 & 3.9 & 4.4 & 0.074 & 0.379 & $\mathbf{0 . 0 4 5}$ & 0.183 \\
Tenderness & 3.8 & 3.0 & 3.5 & 3.8 & 0.144 & 0.330 & $\mathbf{0 . 0 2 1}$ & $\mathbf{0 . 0 4 8}$ \\
Juiciness & 4.4 & 3.7 & 4.0 & 4.2 & 0.093 & 0.961 & $\mathbf{0 . 0 3 9}$ & $\mathbf{0 . 0 2 5}$ \\
Flavor/palatability & 4.7 & 4.1 & 4.4 & 4.5 & 0.078 & 0.182 & $\mathbf{0 . 0 4 3}$ & 0.060 \\
\hline
\end{tabular}

$L$, lightness; $a$, redness; $b$, yellowness; WBSF, Warner-Bratzler Shear Force; $C$, significant effect of sex category (bulls - steers); $A$, significant effect of age at slaughter (15-18 months); $C \times A$, significant effect of interaction.

The $P$ value in bold is significant.

(Miller, 2001). The pH of beef is also correlated with its color, which is considered an important quality indicator by consumers (Filipcik et al., 2009). DFD (dry, firm, dark) meat has greater musty/moldy, cowy/grassy or bloody/serumy aromatic flavors and very high beef flavor intensity (Miller, 2001). Pre-slaughter stress and excitation are responsible for an increased $\mathrm{pH}$ and a darker color of meat. Therefore, transport and pre-slaughter operations should be carried out properly (Tatum et al., 2007) so as to prevent undesirable discoloration of meat which could negatively affect its consumer appeal (Mach et al., 2008). No significant differences in the color of LT were found between bulls and steers or age groups which could result from adequate pre-slaughter conditions, in particular the fact that the animals were kept in the lairage in individual boxes with free access to water, which could contribute to optimal $\mathrm{pH}$ levels.

The taste of beef is mostly determined by the amount and distribution of IMF, whereas texture is affected by factors such as animal species, breed, gender, age and management system (Hocquette et al., 2010; Bonfatti et al., 2013; Modzelewska-Kaptituła and Nogalski, 2014). Beef texture can be evaluated with the use of instrumental methods or sensory analysis. In comparison with sensory analysis, instrumental measurements are faster and ensure higher reproducibility and repeatability of results. Beef should be tender and juicy, should have a desirable aroma and taste, and should be quick and easy to prepare. Consumers attach increasing importance to the above attributes of beef and its fat content. According to consumers, tenderness is an important indicator of meat quality. The maximum shear force measured in the Warner-Bratzler test (WBSF) is a param- eter correlated with meat tenderness. The values of WBSF varied depending on sex category and were lower in meat from steers (Table 5), which was also tenderer than meat from bulls. There are clear correlations between meat tenderness vs. connective tissue content, fat content and muscle fiber thickness. In a study by Wheeler et al. (2005), the coefficient of correlation $r$ between IMF and tenderness was determined at 0.47 . In our study, beef from young bulls and steers only slightly differed in tenderness. Bulls have a significantly higher amount of collagen in the LT muscle, compared with steers and heifers (Zhang et al., 2010), which decreases meat tenderness (Bureš and Bartoň, 2012). Steers usually receive higher scores for tenderness (Tatum et al., 2007). According to Miller et al. (2001), consumers perceive beef with a WBSF below $4.3 \mathrm{~kg} \mathrm{~cm}^{-2}$ as tender and that with a WBSF above $4.9 \mathrm{~kg} \mathrm{~cm}^{-2}$ as tough. The analysis of the effect of age at slaughter on beef tenderness and juiciness revealed that younger bulls and older steers received higher scores for those parameters. The meat of bulls slaughtered at 18 months of age was least tender and juicy. Beef quality is influenced by age at slaughter, and Sakowski et al. (2001) demonstrated that sensory properties fully manifest themselves in animals older than 18 months of age. In our study, beef from younger animals, i.e. 15-month-old bulls and 18-month-old steers, was characterized by a desirable aroma and taste. In an earlier study investigating crossbred HF $\times$ Charolais bulls and steers, beef from steers scored higher for palatability and tenderness (Nogalski et al., 2018). Age at slaughter had no significant effect on the sensory properties of meat, although IMF content was significantly influenced by both the sex category and slaughter age of cattle. 


\section{Conclusions}

In both age groups, crossbred $\mathrm{HF} \times \mathrm{HH}$ bulls, as compared with steers, were characterized by a higher dressing percentage, higher scores in the EUROP classification system, lower fat content, higher weight of most valuable primal cuts and more desirable tissue composition of the three-rib section. The slaughter value of bulls improved with age, which predisposes them for a fattening period of at least 18 months. However, prolonged fattening deteriorated the sensory quality and processing suitability of beef from bulls. The opposite trend was noted in steers. The carcasses of older animals were characterized by higher fatness, which was confirmed by 2 -fold higher IMF content. Fat from steers had a healthier n-6 / n-3 PUFA ratio and ensured beef marbling desired by consumers. Beef from steers was naturally tender and juicy. The results of this study may encourage producers to raise steers known for producing high-quality beef.

Data availability. The original data are available upon request from the corresponding author.

Author contributions. ZN and CP designed the experiment. PPP, $\mathrm{ZN}$, MSS and DK performed the experiments and analyses. ZN performed the statistical analysis. PPP interpreted the data. PPP prepared the manuscript with contributions from all coauthors.

Competing interests. The authors declare that they have no conflict of interest.

Acknowledgements. This research was performed as part of project no. POIG.01.03.01-00-204/09 Optimizing of Beef Production in Poland in accordance with the "From Farm to Fork" strategy cofinanced by the European Regional Development Fund under the Innovative Economy Operational Program 2007-2013.

Edited by: Steffen Maak

Reviewed by: three anonymous referees

\section{References}

Ahnström, M. L., Hessle, A., Johansson, L., Hunt, M. C., and Lundström, H.: Influence of slaughter age and carcass suspension on meat quality in angus heifers, Animal, 6, 1554-1562, 2012.

Alfaia, C. P. M., Alves, S. P., Martins, S. I. V., Costa, A. S. H., Fontes, C. M. G. A., Lemos, J. P. C., Bessa, R. J. B., and Prates, J. A. M.: Effect of feeding system on intramuscular fatty acids and conjugated linoleic acid isomers of beef cattle, with emphasis on their nutritional value and discriminatory ability, Food Chem., 114, 939-46, 2009.

Baryłko-Pikielna, N., Kossakowska, T., and Baldwin Z.: The selection of optimal method to prepare beef and pork for the sensoric evaluation, Annals of the Institute of Meat Industry, 1, 111-132, 1964.

Bonfatti, V., Albera, A., and Camier, P.: Genetic associations between daily BW gain and live fleshiness of station tested young bulls and carcass and meat quality traits of commercial intact males in Piemontese cattle, J. Anim. Sci., 91, 2057-2066, 2013.

Bureš, D. and Bartoň, L.: Growth performance, carcass traits and meat quality of bulls and heifers slaughtered at different ages, Czech J. Anim. Sci., 57, 34-43, 2012.

Christensen, M., Ertbjerg, E., Failla, S., Sańudo, C., Richardson, R. I., Nute, G. R., Olleta, J. L., Panea, B., Albertí, P., Juárez, M., Hocquette, J. F., and Williams, J. L.: Relationship between collagen characteristics, lipid content and raw and cooked texture of meat from young bulls of fifteen European breeds, Meat Sci., 87, 61-65, 2011.

Daley, C. A., Abbott, A., Doyle, P. S., Nader, G. A., and Larson, S.: A review of fatty acid profiles and antioxidant content in grass-fed and grain-fed beef, Nutr. J., 9, 10, https://doi.org/10.1186/1475-2891-9-10, 2010.

Department of Health: Nutritional aspects of cardiovascular disease, Report on Health and Social Subject No. 46, Her Majesty's Stationery Office, London, 1994.

FAO: Fats and fatty acids in human nutrition, Report of an expert consultation, Geneva, FAO Food and Nutrition Paper 91, 103, 2008.

Filipcik, R., Subrt, J., and Bjelka, M.: The factors influencing beef quality in bulls, heifers and steers, Slovak J. Anim. Sci., 42, 54$61,2009$.

Hocquette, J. F., Gondret, F., Baeza, E., Medale, F., Jurie, C., and Pethick, D. W. : Intramuscular fat content in meat-producing animals: development, genetic and nutritional control, and identification of putative markers, Animal, 4, 303-319, 2010.

Integrated Agricultural Market Information System: MRiRW, Warsaw, Poland, available at http://www.minrol.gov.pl/Rynki-rolne/ Zintegrowany-System-Rolniczej-Informacji-Rynkowej/

Biuletyny-Informacyjne/Rynek-wolowiny-i-cieleciny, last access: May 2017.

Kamieniecki, H., Wojcik, J., Pilarczyk, R., Lachowicz, K., Sobczak, M., Grzesiak, W., and Blaszczyk, P.: Growth and carcass performance of bull calves born from Hereford, Simmental and Charolais cows sired by Charolais bulls, Czech J. Anim. Sci., 54, 4754, 2009.

Leheska, J. M., Thompson, L. D., Howe, J. C., Hentges, E., Boyce, J., Brooks, J. C., Shriver, B., Hoover, L., and Miller, M. F.: Effects of conventional and grass-feeding systems on the nutrient composition of beef, J. Anim. Sci., 86, 3575-85, 2008.

Litwińczuk, Z., Chabuz, W., Domaradzki, P., and Jankowski, P.: Slaughter value of young Polish Black-and-White, WhiteBacked, Polish Holstein-Friesian and Limousin bulls under semiintensive fattening. Ann. Anim. Sci., 12, 159-168, 2012.

Macedo, L. M., Prado, I. M., Prado, J. M., Rotta, P., Prado, R. M., Souza, N. E., and Prado, I. N.: Chemical composition and fatty acids profile of five carcass cuts of crossbred heifers finished in feedlot, Semin-Cienc. Agrar., 29, 597-608, 2008.

Mach, N., Bach, A., Velarde, A., and Devant, M.: Association between animal, transportation, slaughterhouse practices, and meat pH in beef, Meat Sci., 78, 232-238, 2008.

Miciński, J., Klupczynski, J., Ostoja, H., Cierach, M., Dymnicka, M., Lozicki, A., and Daszkiewicz, T.: The effect of breed and 
feeding of young bulls on the classification results of their carcasses under the "EUROP" system and on the evaluation of their meat texture, Food Science Technology Quality, 3 (Suppl.), 147156, 2005.

Miller, R. K.: Beef flavor: A white paper, A paper prepared for the National Cattlemens' Beef Association, Centennial, CO, 2001.

Miller, R. K., Moeller, S. J., Goodwin, R. N., Lorenzen, C. L., and Savell, J. W.: Consistency in meat quality, in: Proceedings of the 46th international congress of meat science \& technology, Buenos Aires, Argentina, 566-580, 2000.

Missio, R. L., Brondani, I. L., Restle, J., Souza da Silva, J. H., Silveira, M. F., and Silva, V. S.: Non-integrant components of the carcass from young bulls fed different concentrate levels, Rev. Bras. Zootec., 38, 906-915, 2009.

Modzelewska-Kapituła, M. and Nogalski, Z.: Effect of gender on collagen profile and tenderness of infraspinatus and semimembranosus muscles of Polish Holstein-Friesian x Limousin crossbred cattle, Livest. Sci., 167, 417-424, 2014.

Moletta, J. L., Prado, I. N., Fugita, C. A., Eiras, C. E., Carvalho, C. B., and Perotto, D.: Carcass and meat characteristics of steers or bulls, finished in feedlot and fed with diets containing three levels of concentrate, Semina: Ciênc. Agrár., Londrina, 35, 1035-1050, 2014.

National Research Institute of Animal Production - INRA: Nutrient Requirements of Ruminants. Nutritional value of French and Polish ruminant feeds, edited by: Strzetelski, J., Published by the National Research Institute of Animal Production in Cracow, Poland, 2009.

Nogalski, Z.: Głos w dyskusji, Przegląd Hodowlany, 5, 22-24, 2015 (in Polish).

Nogalski, Z. and Kijak, Z.: Fattening performance and slaughter value of the offspring of Black and White cows and Welsh Black bulls, Czech J. Anim. Sci., 46, 68-73, 2001.

Nogalski, Z., Pogorzelska-Przybylek, P., Wielgosz-Groth, Z., Sobczuk-Szul, M., Purwin, C., Winarski, R., and Niedźwiedź, J.: Slaughter value of crossbred beef steers as depending on fattening intensity and slaughter age of animals, Food Science Technology Quality, 3, 51-60, 2013a.

Nogalski, Z., Wroński, M., Wielgosz-Groth, Z., Purwin, C., Sobczuk-Szul, M., and Mochol, M.: The effect of carcass conformation class (EUROP system) on the slaughter quality of young crossbred beef bulls and Holstein-Friesians, Ann. Anim. Sci., 13, 23-28, 2013b.

Nogalski, Z., Wielgosz-Groth, Z., Purwin, C., Nogalska, A., Sobczuk-Szul, M., Winarski, R., and Pogorzelska, P.: The effect of slaughter weight and fattening intensity on changes in carcass fatness in young Holstein-Friesian bulls, Ital. J. Anim. Sci., 13, 66-72, 2014a.

Nogalski, Z., Wielgosz-Groth, Z., Purwin, C., Sobczuk-Szul, M., Mochol, M., Pogorzelska-Przybylek, P., and Winarski, R.: Effect of slaughter weight on the carcass value of young crossbred (Polish Holstein Friesian $\times$ Limousin) steers and bulls, Chil. J. Agr. Res., 74, 59-66, 2014b.

Nogalski, Z., Pogorzelska-Przybylek, P., Sobczuk-Szul, M., Nogalska, A., Modzelewska-Kapitula, M., and Purwin, C.: Carcass characteristics and meat quality of bulls and steers slaughtered at two different ages, Ital. J. Anim. Sci., 17, 279-288, 2018.
PN-ISO 4121:1998: Sensory Analysis - Methodology - Evaluation Of Food Products By Methods Using Scales, Polish Committee for Standardization, Warsaw, Poland, 1998.

PN-88/A-82003/Ap1:2004: Beef. Primal cuts, Polish Committee for Standardization, Warsaw, Poland, 2004 (in Polish).

Prado, I. N., Passetti, R. A. C., Rivaroli, D. C., Ornaghi, M. G., de Souza, K. A., Carvalho, C. B., Perotto, D., and Moletta, J. L.: Carcass Composition and Cuts of Bulls and Steers Fed with Three Concentrate Levels in the Diets, Asian Austral. J. Anim., 28, 1309-1316, 2015.

Realini, C. E., Duckett, S. K., Brito, G. W., Dalla Rizza, M., and Mattos, D.: Effect of pasture vs. concentrate feeding with or without antioxidants on carcass characteristics, fatty acid composition, and quality of Uruguayan beef, Meat Sci., 66, 567-577, 2004.

Reddy, B. V., Sivakumar, A., Jeong, D. W., Woo, Y. B., Park, S. J., Lee, S. Y., Byun, J. Y., Kim, C. H., Cho, S. Y., and Hwng, G. I.: Beef quality traits of heifer in comparison with steer, bull and cow at various feeding environments, Anim. Sci. J., 86, 1-16, 2015.

Sakowski, T., Dasiewicz, K., Słowiński, M., Oprządek, J., Dymnicki, E., Wiśniach, A., and Słoniewski, K.: Quality of meat of beef breeds bulls, Med. Weter., 57, 748-757, 2001 (in Polish, English abstract).

Sharman, E. D., Lancaster, P. A., McMurphy, C. P., Garmyn, A. J., Pye, B. J., Mafi, G. G., Goad, C. L., Phillips, W. A., Starkey, J. D., Krehbiel, C. R., and Horn, G. W.: Effect of rate of body weight gain in steers during the stocker phase. I. Growth, partitioning of fat among depots, and carcass characteristics of growingfinishing beef cattle, J. Anim. Sci., 91, 4322-4335, 2013.

Tatum, J. D., Gruber, S. L., and Schneider, B. A.: Pre-harvest factors affecting beef tenderness in heifers, Executive summary prepared for the National Cattleman's Beef Association, available at http://www.beefresearch.org/CMDocs/BeefResearch/PE_ Executive_Summaries/Pre_Harvest_Factors.pdf (last access: July 2016), 2007.

Wajda, S., Kondratowicz, J., Burczyk, E., and Winarski, R.: Slaughter value and quality of meat from beef carcasses classified to different conformation classes in EUROP system, Food Science Technology Quality, 4, 136-147, 2014.

Wheeler, T. L., Cundiff, L. V., Shackelford, S. D., and Koohmaraie, M.: Characterization of biological types of cattle (cycle VII): carcass, yield, and longissimus palatability traits, J. Anim. Sci., 83, 196-207, 2005.

Wielgosz-Groth, Z., Sobczuk-Szul, M., Nogalski, Z., Mochol, M., Purwin, C., and Winarski, R.: Fatty acid profiles of intramuscular, intermuscular, external and internal fat in Polish HolsteinFriesian x Hereford bulls and steers fed grass silage-based diets supplemented with concentrates, Anim. Prod. Sci., 57, 371-377, 2016.

Żegarska, Z., Jaworski. J., and Borejszo, Z.: Evaluation of the modified Peisker method for obtaining fatty acid methyl esters, Acta Acad. Agric. Tech. Olst., Technol. Aliment., 24, 25-33, 1991 (in Polish).

Zhang, Y. -Y., Zan, L. -S., Wang, H. -B., Xin, Y. -P., Adoligbe, C. M., and Ujan, J. A.: Effect of sex on meat quality characteristics of Qinchuan cattle, Afr. J. Biotechnol., 28, 4504-4509, 2010. 